\title{
A ROYAL WASTE OF TIME? PERSPECTIVES ON LITURGY AS SPACE AGAINST WASTE ${ }^{1}$
}

\author{
Johan Cilliers \\ Practical Theology \& Missiology \\ Stellenbosch University
}

\begin{abstract}
In this article a brief look is taken at the so-called 'functionality' and 'nonfunctionality' of the worship service. It is argued that both these notions are necessary if the worship service is to play a meaningful role in matters concerning waste, i.e. matters that affect the dignity of humanity and the eco-system as well. The contention is that the phenomenon of waste should be brought into the space of worship, coram deo. Worship should face waste. The presentation concludes with some liturgical perspectives on worship as space against waste.
\end{abstract}

Key Words: Liturgy; Space; Waste; Play

\section{Liturgy between Play and Purpose}

What is the function of liturgy? What should it achieve? These (types of) questions should probably have preference over questions that concentrate merely on the order of worship services, i.e. the how of liturgy and directives about its choreography or structuring. ${ }^{2}$ Much has been written about the so-called functionality of liturgy. The Dutch liturgist, Gerard Lukken, for instance, already pointed out in his earliest works ${ }^{3}$ that liturgy (inclusive of rituals) has at least seven functions. In later publications he expanded this to ten functions, or as he calls them dimensions, namely a mediatory dimension oriented towards the past (remembrance), a formalising dimension, a concentrating dimension, the cathartic and canalising dimensions, an expressive dimension, an exorcist dimension, an ethical dimension, a social dimension and a political dimension. ${ }^{4}$

Another famous Dutch theologian, Arnold van Ruler, refers to no fewer than twentyone reasons why people should go to church, namely to have a chance at conversion, to uphold a custom, to hold on to a tradition, to experience existence at its fullest, to praise

This article was first delivered as a paper at the annual meeting of The Society for Practical Theology in South Africa at the University of Pretoria, 22 to 24 January 2014, on the theme: Practical theology in Africa and human waste.

2 For an extension of this argument, cf. Johan Cilliers, Liturgie as spel: 'n besinning oor die nie-funksionaliteit van die erediens. Dutch Reformed Theological Journal; NGTT, 2008, Deel 49. No 3 en 4:40-48.

3 Gerard Lukken, Geen leven zonder rituelen. Antropologische beschouwingen met het oog op de christelijke liturgie, Baarn (Gooi \& Sticht) 1986:25-31; also Gerard Lukken, No life Without Rituals. In: Louis van Tongeren and Charles Caspers (eds.) Visibilia Ad Invisibilia, Anthropological, Theological and Semiotic Studies on the Liturgy and the Sacraments. Kampen, Kok Pharos Publishing House, 1994:101-106.

4 Gerard Lukken, No life without Rituals. In: Louis van Tongeren and Charles Caspers (eds.) Per Visibilia Ad Invisibilia, Anthropological, Theological and Semiotic Studies on the Liturgy and the Sacraments. Kampen, Kok Pharos Publishing House, 1994:58-70. 
God, to observe reality, to pray for the world, to understand the meaning of life, to receive salvation, to come to the light, to be incorporated into the community, to confess your faith publicly, to make your contribution in the congregation, to eventually serve in an office, to realise the meaning of Sunday, to participate in the church year, to find rest, to be edified, to be tuned in to another wavelength, to be given guidance and to celebrate the salvation of the world. ${ }^{5}$

Within the South African Reformed perspective the following eight processes have been identified as being part and parcel of liturgy, specifically in relation to the ethical tension between liturgy and life: subversion, freedom, community, articulation, vocation, formation and transformation, confirmation and dedication. ${ }^{6}$

It is interesting to hear how churchgoers themselves answer the above-mentioned question concerning the functionality of liturgy. GB Thompson did empirical research amongst churchgoers to establish precisely what they consider as the most important functions of liturgy and he lists three preferences in the light of the responses: it should represent an oasis of peace and calm in the midst of the unrest of life; it should offer inspiration and hope for the future; the sermon should give practical advice that can be of use during the rest of the week. Although all these issues are obviously important, it is interesting to note that all of them operate on an individualistic level and remain focused on personal experience. ${ }^{7}$

And so one could continue. As a matter of fact, these descriptions of the functionality of liturgy could be expanded even further; it seems as if the possibilities are endless.

Another strand of thought focuses on a dimension that at first glance seems to contradict every functional understanding of liturgy, namely the (non-functional) dimension of play. In reality this does not contradict the above understandings, but rather forms the foundation on which, or space within which, liturgy can function. Liturgy as play does not focus on function and it is functional precisely for this reason. This tension between functionality and non-functionality is expressed poignantly by Marva Dawn:

To worship the Lord is - in the world's eyes - a waste of time. It is, indeed, a royal waste of time, but a waste nonetheless. By engaging in it, we don't accomplish anything useful in our society's terms. Worship ought not to be construed in a utilitarian way. Its purpose is not to gain numbers nor for our churches to be seen as successful. Rather, the entire reason for our worship is that God deserves it... Worship is a royal waste of time that spirals into passion for living as Christians and back into more passionate worship. It is totally irrelevant, not efficient, not powerful, not spectacular, not productive, sometimes not even satisfying to us. It is also the only hope for changing the world. ${ }^{8}$

The notion of play in liturgical context was strongly emphasised by people such as Romano Guardini and Hugo Rahner, two important exponents of the liturgical movement during the

Arnold A van Ruler, Waarom zou ik naar de kerk gaan? Nijkerk: Callenbach, 1972:9-175.

6 Dirkie Smit, Lex orandi, lex credendi, lex (con)vivendi? - Oriënterende inleiding tot liturgie en etiek. NGTT, 2004, 45/3 and 4:887-907.

7 GB Thompson, Treasures in Clay Jars. New Ways to Understand Your Church. Cleveland: The Pilgrim Press, 2003:171.

8 Marva Dawn, A Royal 'Waste' of Time. The splendor of worshipping God and being Church for the World. Grand Rapids, Michigan/Cambridge, UK: William B Eerdmans Publishing Company, 1999:1,17. 
twentieth century. ${ }^{9}$ According to Romano Guardini, liturgy is primarily a game, an apparently aimless exercise - in any case measured by functionalistic standards:

Grave and earnest people, who make the knowledge of truth their whole aim, see moral problems in everything, and seek for a definitive purpose everywhere, tend to experience a peculiar difficulty where the liturgy is concerned... They must learn not to be continually yearning to do something, to attack something, to accomplish something useful, but to play the divinely ordained game of the liturgy in liberty and beauty and holy joy before God. ${ }^{10}$

Saying this, Guardini in no way denies that liturgy also has other dimensions, and that it can and should pursue certain pastoral, didactical and ethical 'goals'. On the contrary, according to him, the church should not only build up the Opus dei merely for the pleasure of beautiful symbols, church language and stately gestures, but also for the sake of satisfying our desperate spiritual need. If we were untrue to the latter purpose, we would be untrue to the Gospel itself.

So this play or game is never merely for the sake of superficial frivolity, but often full of tears - because God's intention with life is thwarted and sabotaged in so many ways. In fact, the play we are talking about here is characterised by ambivalence, by a polarity, a constant reciprocity between what is and what should be, or ought to be. ${ }^{11}$ It is play without holding back, but at the same time also full of anticipation of a world which is playfully hoped for. In the same sense the liturgy should not only be able to laugh, but also to lament - because life is often inundated by worry and woe; it also groans in the pain of expectation of a better world. ${ }^{12}$ A liturgy that expresses all these experiences of disorientation cannot and does not have to avoid the reality of sorrow and suffering, of pollution and poverty, of children playing on dump heaps. Liturgy is the play of God's grey children. ${ }^{13}$

In this play lies the highest 'function' of liturgy. Play and purpose do not contradict one another; feast and function go together; praise and programmes are, or should be, in step. If we abstract play from purpose, we end up with liturgical inversion; if we abstract purpose from play, the result could be a pathological quest for liturgical relevancy. Liturgy opens up a space where the healthy tensions between play and purpose become evident, and in this sense it is also a space against waste. ${ }^{14}$

9 Cf. their major works in this regard: Romano Guardini, The Spirit of the Liturgy. New York: Crossroad, 1997; Hugo Rahner. Man at Play. New York: Herder and Herder, 1965.

10 Guardini, The Spirit of the Liturgy, 61:71-72. According to Ralph Sauer, play is part of feasting, a play that does not have any specific aim, but rests in itself - it is an aim in itself. Liturgy as aimless play is a depiction of God who rests in God self, and is meaning as such. Ralph Sauer, Die Kunst, Gott zu feiern. Liturgie wiederentdecken und einüben. München: Kösel, 1996:56.

11 A Paus, Liturgie als Spiel? In Communicatio Fidei: Festschrift für Eugen Biser zum 65. Geburtstag. Eds. H Bürkle \& G Becker. Regensburg: Pustet, 1983:300-301.

12 Cf. Rom 8:22.

13 The use of the term play is, of course, nothing new in theology - in the scriptures we already hear that wisdom played like a child before the father on the eve of creation (Prov. 8:30). Diverse thinkers such as Hieronymus, Origines, Gregory of Nissa, Maximus and other mystics represent a theology which could be considered as a counter-voice to the official onto-theological traditions of the day, and which often, as misunderstood and even mocked movements, wished to reclaim humanity as homo ludens, as playful human beings who work co-creatively in the world with the playing God (deus ludens).

14 I use the notion of space in conjunction with liturgy deliberately. For an exposition of the spatial dimensions of liturgy, cf. Johan Cilliers, In die omtrek van die Gees: 'n besinning oor die ruimtelikheid van liturgie.

Praktiese Teologie in Suid-Afrika 2008, Vol 23 (2):1-21. 


\section{What a Waste}

The issue of waste has indeed escalated into a planet-threatening reality. South Africa generates approximately 108 million tonnes of waste per annum - and it is growing. In $2011,55 \%$ of this waste was classified as 'general waste', 44\% was 'unclassified waste', and $1 \%$ was labelled as 'hazardous waste'. ${ }^{15}$ The Member States of the European Union (EU) produce more than 2 billion tonnes of waste, including hazardous materials, every year. And this figure is rising steadily. The situation is even more alarming in the countries of Eastern Europe, Caucasus, and Central Asia. The waste generated there accounts for nearly 4 billion tonnes (2009). ${ }^{16}$ And so we could go on.

Water pollution has become a particular threat in South Africa. South Africa is a place of many paradoxes. ${ }^{17}$ Water is no exception. In South Africa we have some of the most breathtaking waterfalls, dams, oceans, rivers - but, paradoxically, not only a scarcity of fresh water resources in comparison to our population growth, but also pollution of these scarce sources on a shocking scale. We actually have a water crisis. South Africa is by some standards, a 'dry' country, and the water sources that we have, are under threat.

The main factors contributing to the deterioration of water quality in South Africa are salinization, eutrophication, disease-causing micro-organisms and acidification. South Africa is facing a water supply crisis caused by a combination of low rainfall, high evaporation rates, an expanding economy and a growing population whose geographical demands for water do not conform to the distribution of exploitable water supplies. ${ }^{18}$

In 2005 , more than $95 \%$ of the country's freshwater resources had already been allocated for usage in different spheres of our society. The water quality of these resources has, however, declined due to increased pollution caused by industry, urbanization, afforestation, mining, agriculture and power generation. Exacerbating factors are South

15 The National Environmental Management Waste Act (Act 59 of 2008) (RSA, 2009) provides the following definitions of the different types of waste: General Waste: "Waste that does not pose an immediate hazard or threat to health or the environment, and includes domestic waste, building and demolition waste, business waste; and inert waste". Hazardous Waste: "Waste that contains organic or inorganic elements or compounds that may, owing to the inherent physical, chemical or toxicological characteristics of that waste, have a detrimental impact on health and the environment". Unclassified Waste: Refers to waste streams that are listed both under general and hazardous waste in the Waste Information Regulations. These waste streams are typically generated in high volumes but are believed to pose relatively low hazard to the environment and human health (Department of Water Affairs \& Forestry, 1998). To improve the classification of waste in South Africa a more comprehensive system of classification is being developed in the form of the draft Waste Classification Regulations in terms of the National Environmental Waste Management Act (DEA, 2009). As a result a number of waste categories that were previously considered to be unclassified waste will be monitored and classified as either general or hazardous from 2012 onwards. Since the DEA baseline report predates this development a considerable amount of waste is still noted as unclassified. Source: DEA. (2012). National Waste Information Baseline Report.

16 United Nations for Economic Commission for Europe (UNECE),

http://www.unece.org/statistics/news/newswaste-statistics.html

17 There exists, for instance, the paradox between poor and rich, and in particular extremely poor and extremely rich. There is the paradox between luxurious mansions and affluent estates, and struggling townships and dilapidated shacks - often situated just a few kilometers from one another. There is the paradox - in comparison to many other countries - between the highest figures of unemployment, and the lowest rates of life expectancies; the highest forms of educational inequalities, and the lowest forms of productivity rates; the most sophisticated technological advances in the world (for example the largest disk-shaped telescope, SKA, being constructed in the Karoo), and a crumbling provider of electricity (Eskom); between being able to host one of the most successful Soccer World Cups in history (2010), and experiencing some of the worst bouts of xenophobia ever (in 2008), etc.

18 CSIR perspective on water in South Africa - 2010. 
Africa's outdated and inadequate water treatment and sewage treatment plant infrastructure and unskilled operators - underlined by instances such as the recent service delivery protests against a lack of water at the informal settlement in Mothutlung, near Brits in the North West Province, resulting in the death of four protestors after clashes with the police.

But paradoxes often open up spaces of creative tension. And it is exactly this tension of pristine sources and wanton pollution, of creation and chaos that calls for, and simultaneously challenges, liturgy as a space against waste. But what do we mean with 'against'?

\section{Liturgy as Space Against Waste}

In what follows, I offer four brief perspectives.

- First, 'against', in its liturgical sense at least, does not indicate a general negative attitude towards life. Unfortunately, this has often been the case. 'Protestantism' does not equate a constant protest against something or someone, but rather a way to live within the context of a new identity. (Protestant) Liturgy should consequently also not be usurped to become a constant campaign against certain realities, but should rather be an expression of our new identity in Christ. Perhaps we should critically revisit the suffix -ism in Protestantism. It could be misconstrued as a syndrome of: we-are-againstall-and-everything. Then the idea of liturgical functionality, abstracted from the dimension of play, becomes a negative and perhaps even destructive ideology.

It would in fact be interesting to do some research on what types of closed ecclesiologies lurk behind certain negative conceptions of Protestantism - an ecclesiology that in fact needs the 'enemy' in order to function and indeed to exist. In this sense the 'enemy' not only threatens, but also affirms; if the enemy is no longer there, such Protestants no longer have an identity and existence. It signifies a type of Protestantism, even a God-image that exists by grace of the 'enemy'. In such -isms the gospel is often deteriorated into an 'anti-something': anti-humanist, anti-communist, anti-gamble, antihomosexuality, anti-this and anti-that. 'Anti' then becomes an essential part of such modes of faith - which resembles Zoroastrianism, rather than Christianity. ${ }^{19}$

We should take care not to over-ethicise life in liturgy. We are reminded of Dietrich Bonhoeffer's contention that the intention of God's law is to create structures within which we can experience and enjoy everyday life, and that we are not called to make major ethical decisions every second of every day. Therefore we should also not overburden life in a pathological manner with the ethical. ${ }^{20}$ The whole of life is not ethics. But, says Bonhoeffer, sometimes situations and conditions arise in life in which the 'normal', everyday existence is so shattered, so ravaged, that the Church cannot avoid uttering a clear, ethical word. Then the gospel must be proclaimed as the concrete law for the hour. In this sense, the Church does not proclaim 'eternal principles' that profess 'truth that is applicable everywhere', but rather the gospel as law for the hour, being true here and now. Not all that is 'eternally' true is of necessity true 'today'. The question is: does the pollution of our planet not constitute an ethical dilemma of such magnitude, that the Church should urgently proclaim the gospel as truth-for-today, indeed as law for this late hour (before midnight)?

\footnotetext{
19 Cf. Johan Cilliers, God for Us? An analysis and evaluation of Dutch Reformed preaching during the Apartheid years. Stellenbosch: Sun Press, 2006:30f. 
- Second, (Protestant) liturgy is, obviously, 'against' negative and destructive forces and realities. When play, in turn, is abstracted from purpose, liturgy falls silent when and where it should speak. ${ }^{21}$ Silence is not always golden. ${ }^{22}$ We have to protest, to oppose, to speak and act out - against. But we do this from a theological basis, not as followers of the latest (ecological) trend.

I take my cue here from the famous Roman Catholic monk, Teilhard de Chardin, who was way ahead of his times in the debate about science and faith, and in particular about the relationship between evolution and creation. Obviously I cannot do justice to the richness of his theological and philosophical thought here. ${ }^{23}$ What I find interesting however, is his understanding of the Cosmic Christ - and he takes his cue in turn from the Apostle Paul. ${ }^{24}$ For De Chardin, all of creation is underway, also through evolution, to the ultimate fulfilment under the Omega, Christ. All of reality is converging towards this pleroma, this fullness, this final unification of all things under Christ. This movement finds its culmination in the final triumph over all destructive powers. At present, however, there are still counter-powers, resisting this movement towards the fulfilment. These counter-powers do not converge, but rather create chaos; do not fulfil, but instead fragment.

So, if we venture an interpretation of De Chardin, we could say that the pollution of creation, with the escalation of waste, may be seen as being part of this countermovement, away from the unification under Christ, back towards the chaos. Pollution stands in paradox to the pleroma - where and when all of creation will finally come to rest. Pollution opposes the ultimate peace and fulfilment of God's creation and in doing so represents the chaos that threatens this creation.

As space against waste, liturgy opposes these opposing powers; represents a counter-movement against the counter-powers; protests against the pollution that seeks to draw creation back to chaos. In liturgy we are indeed co-workers with Christ, as Paul states, co-converging towards the pleroma. ${ }^{25}$

- Third, liturgy protests, but is not 'against' chaos, per se. Chaos can in fact be the first step towards order; the presupposition to new creation. Chaos can become the playground for new creation. This time I take my cue from a change in aesthetical paradigm during the $19^{\text {th }}$ century. During this era, the 'other side of beauty' was rediscovered, inter alia by people such as Arnold Ruge, Friedrich Vischer, and Karl

21 This syndrome of silence is of course not new, at least within certain sectors of the South African context. Research done on trends in Afrikaans religious programmes as far back as 1987 indicates that the religion that was offered to ordinary Afrikaans-speaking people then was almost always imperative in nature, but not as an appeal that affects the daily and concrete reality. It was rather a type of alien-to-daily-life, non-existential appeal on the grounds of pietistic potential. The programmes' contents said virtually nothing about the issues that, for instance, received attention in the daily press. This research, conducted in conjunction with the Department of Journalism at Stellenbosch University, found that not one of the ten most commented on issues of the day were reflected in the sermons that were broadcast. Cf. BA Müller,. Tendense in Afrikaanse Godsdiens Programme. Stellenbosch: Stellenbosch University, 1987:44-46.

For an exposition of the positive meaning of silence within liturgical context, cf. Johan Cilliers, Silence is golden: liturgy beyond the edge of language. Praktiese Teologie in Suid-Afrika, 2008, 23/1:19-35. His thoughts on the relationship between evolution, science and faith can be read in his book Christianity and Evolution. London: Collins, 1977. 
Rosenkranz. ${ }^{26}$ Rosenkranz spoke about the Ästhetik des Hässlichen (aesthetics of ugliness), and called ugliness Negativschönen (negative beauty - but still beauty). ${ }^{27}$ According to this perspective, beauty should rather be understood as a space where all the disorders, the imperfections, even the evils and the one-sidedness of our experiences of reality do not necessarily estrange us from the truth, but rather where we have the possibility of stumbling upon 'truth'.

The ontological function of (ugly) beauty is therefore to narrow the chasm between ideal and reality. ${ }^{28}$ In this sense, 'beauty' lies on the borders between so-called order (proportion) and so-called chaos (disproportion). Beauty is simultaneously the order of change and the change of order, and as such it is fragile, fleeting, endangered, and contingent. ${ }^{29}$ According to Rainer Maria Rilke beauty is nothing more than a terrible beginning (Schrecklichen Anfang) to unthought-of possibilities. ${ }^{30}$

Within this paradigm, chaos is not viewed as the negative of order; it is not nonorder. ${ }^{31}$ The Greeks already understood chaos as the possibility for order, as space and horizon filled with potential. ${ }^{32}$ Nietzsche spoke about the beautiful chaos of being. ${ }^{33}$ In this sense, beauty could be interpreted as the dialectic or paradox, i.e. as the perpetual and reciprocal movement between chaos and order. ${ }^{34}$ Within this perspective, waste (or: chaos) is allocated a certain form of worth (i.e. possibility of new creation), and this brings us to our fourth perspective.

26 Cf. the discussion by Renate Reschke, Schön/Schönheit, Ästhetische Grundbegriffe 5. Stuttgart, Weimar: JB Metzler, 2010:416f.

27 Karl Rosenkranz, Ästhetik des Hässlichen (1853). Leipzig: D Kliche, 1996:5. According to him, “Ästhetiker haben nicht das Recht, Erfahrungen der Wirklichkeit allein mit erträglichen Stichworten vom Edlen, Reinen un Schönen zu reflektieren.” Rosenkranz, Ästhetik des Hässlichen, 9.

Reschke, Schön/Schönheit, 429.

30 Rainer Maria Rilke, Duineser Elegien, in: Rilke, Werke in drei Bänden, hg. H Nalewski, Bd. 1. Leipzig: D Kliche, 1978:579.

31 This relationship between the proportion of order and the disproportion of chaos is important for our understanding of beauty. Disproportion of chaos is not the deformity of proportionate order. Chaos is something in itself - as is order. The link between these two realities could be described as beauty. Beauty exists in the tentative space between proportionate order and disproportionate chaos. The quest for beauty is sparked off by this tension; it is perpetually energised by the movement from disproportion to proportion, i.e. from chaos to order. Understood in this sense, beauty therefore does not exclude the ugly (or: disproportionate), but in fact incorporates it in its quest for (healing of) proportion. The very existence of the tension created by disproportion kindles a faith that is in search of beauty (fides quaerens pulchrum).Cf. Johan Cilliers, Fides Quaerens Pulchrum: Practical Theological Perspectives on the Desire for Beauty. Scriptura: International Journal for Bible, Religion and Theology in Southern Africa 2011; 3 (108):257-268. This is indeed particularly true of faith and theological aesthetics. The beauty of God is often revealed exactly under circumstances of chaotic disproportionateness, which could be viewed as disturbing ugliness. But it could also be viewed as 'a beautiful representation of ugliness.' Cf. Umberto Eco, On Beauty. London: Secker \& Warburg, 2004:134. Cf. also Paul Evdokimov, The Art of the Icon: A Theology of Beauty. New York: Oakwood Publications, 1996:309f.

32 Bianca Theisen, Chaos-Ordnung, Ästhetische Grundbegriffe 1. Stuttgart, Weimar: JB Metzler, 2010:754.

33 “...schöne Chaos des Daseins.” Friedrich Nietzsche, Die fröhliche Wissenschaft (1882), in: Nietzsche (KGA), Abt. 5, Bd. 2, 1973:201.

34 These developments underlined the fact that, in a sense, 'beauty' does not exist in itself, but always within the realm of paradox: out of the experiences of suffering and threat, i.e. chaotic disproportionateness, emerges the quest for beauty as healing of proportions. Cf. Reschke, Schön/Schönheit, 398. 
- Fourth, liturgy as space against waste views waste as a playground for new creation, from the perspective of re-purposing. It brings play and purpose together. The notion of re-purposing is best illustrated aesthetically - taking as example an art work by the somewhat enigmatic German artist Joseph Beuys (1921-1986).

Beuys was injured during World War Two, and spent some time in a military hospital. During his recovery, he experienced firsthand the ravages of human waste and indignity, of destruction and chaos, of death and decay. He was struck particularly by the medical waste created by the hospital - used needles, blood plasma containers and blood-soaked bandages piling up everywhere. In an art work, entitled Crucifixion Installation $^{35}$, he makes use of items from this form of waste, and, in an aesthetical sense, re-purposes it in the light of the salvific work of Christ.

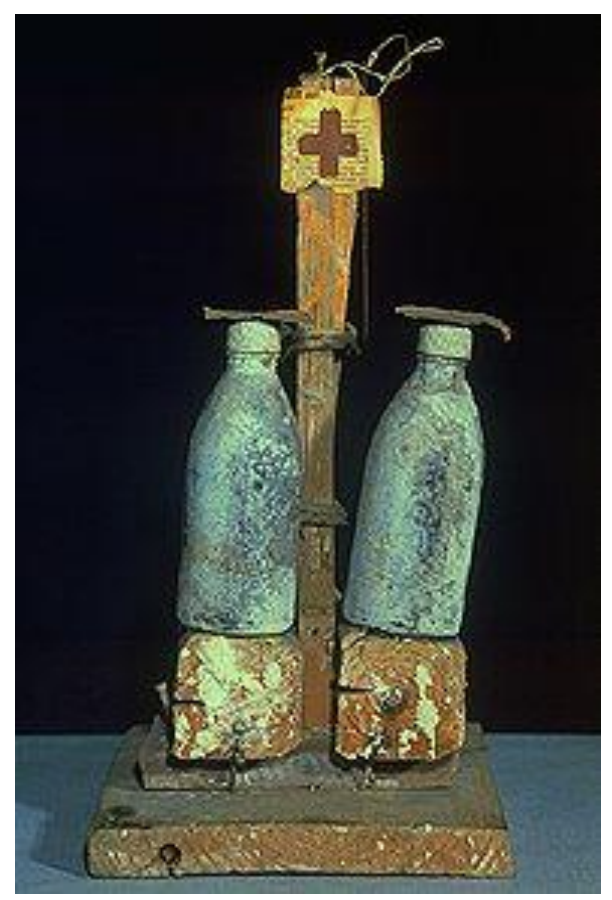

This particular installation of Beuys went through three stages. First he felt the need to create a figurative embodiment of the entirety of Christian experience; second he was overcome by a feeling of paralyzing emptiness at the death of Christ; and third he felt the intense desire to embody the mystical power of Jesus' death. He described the process as follows: "For me it was a question of showing the reality of the energy. A permanently self-reinforcing existence. It isn't a question of embodying or depicting a historical event. It's about making reality present.",36

35 1962/1963, Wood, bottles, electrical cable, wire, paper, oil, plaster, nails, needles, 42,5 x 19 x $15 \mathrm{~cm}$, (C) VG Bild-Kunst, Bonn 2006.

36 Quoted from Pierre Guillet de Monthoux. The art firm: aesthetic management and metaphysical marketing. Chicago: Stanford University Press, 2004:6. 
Although the crucifix installation of Joseph Beuys depicted above retains traces of the traditional image of the crucifixion, there is also a complete renunciation of realistic, figural representation. This heightens the metaphorical significance of the objects that Beuys introduces into his artwork.

The nails and needles on the installation for instance allude to the tools used in afflicting Christ with suffering, but they also indicate physical and mental pain in general. It is quite interesting to note the role that the concept of blood plays in this installation. Three blood-red crosses (unfortunately not all seen in the depiction above) leave the viewer with no doubt as to the theme of the work, and the two old empty plastic blood plasma containers (as used in the military hospital), which symbolise blood as a life-giving fluid, cannot escape attention. It is, however, live-giving that is inseparably linked with suffering; new creation flowing forth from chaos.

Scraps of newspaper with some words on them (unfortunately also not visible on the image) form a collage-effect and link two concepts in a contemporary manner: on the one hand, written on the bottle on the right, the term 'guilt' is quoted from the world of finance; on the other, on the left-hand bottle, one can see an engagement announcement. In this way, a sign of love is linked to the ideas of guilt and retribution. The artist calls for remembrance of the past, but in such a fashion that the timeless themes of life and guilt, blood and suffering, life and death are re-imagined.

In short: scrap becomes symbols of salvation; waste receives metaphorical significance for re-purposing.

\section{Conclusion: A Liturgy of Re-purposing, from Waste to Worth}

Liturgy represents a space against waste, but in such a manner that waste is viewed as a possibility for re-purposing. ${ }^{37}$ In a sense, God specialises in the re-purposing of waste. Nobody expresses this better than Chrysostomus:

The people, once less sensitive than stones, are raised to the worthiness of angels in one deed of God's grace, simply through God's Word and their faith, without any merit on their side. This is the glory and richness of the mystery of Christ. It is like when a scruffy and mangy dog, ugly and deformed, which cannot even move itself anymore but lies with four legs in the air, is instantly transformed into a human being and set on a royal throne. It is like when people who once worshipped the stars and the earth, have now gained insight that they are better than the heavens and the earth and that the whole world is there at their service. Once they decayed in the dungeons and chains of the devil, but now, all of a sudden, they stand high above him, and they flagellate him. First they were the captives and slaves of the demons, but now they have become part of the body of the Lord that reigns over angels and archangels. First they were without knowledge of God, now, in an instant, they sit on the throne next to God. ${ }^{38}$

37 It is interesting to note that someone like Jürgen Moltmann regards the prefix 're-' as ironic, even negative. Jürgen Moltmann, Geloof in de toekomst. Utrecht: Ambo, 1969:32-33. According to him, movements such as the renaissance and the reformation, as well as concepts like revolution, revival, renewal and restoration, all re(!)veal a longing for a (golden) past, which, in itself, implies a cyclical understanding of history. It represents change while 'dreaming backwards'. He rather opts to embrace the completely new reality (novum) instead of the old (re). This prompts the question: Should we not rather speak of pro-volution, etc., and, in this sense, also of 'pro-purposing'?

38 Translated from Kurt Ihlenfeld, Te deum heute. 365 Texte zur Krisis des Christentums. Witten u. Berlin: Eckart, 1965:35. 
This is re-purposing, par excellence.

But, how do we move, liturgically speaking, from waste to worth? Through purposeful playfulness; and playful purposefulness. Of course, some people may say that all of this is impractical, even wishful thinking, at best merely the usage of abstract theological concepts, with no links to (real) life - especially if we argue from within a context of affluence. Indeed, we may think, a royal waste of time. Not so for the so-called 'garbage people of Cairo'. They have, as Coptic Christians, taken waste seriously, for many decades now, and view and re-purpose waste as a type of leitourgia, as liturgy-for-life; liturgy-on the-street.

It is not possible to do justice to the rich history and tradition of the Zabbaleen literally, 'garbage people' of Cairo, within the limitations of this presentation. ${ }^{39}$ For half a century, they have not only sustained themselves on the city's discards, but they do this from a specific Christian-liturgical point of departure. On the surface it looks as if the Zabbaleen, now numbering over 40 000, are simply running highly successful recycling micro-enterprises that collect 4000 tonnes of rubbish each day - about a third of Cairo's output. But on a deeper level there are theological-liturgical foundations for their activities.

Their acts of re-purposing are in fact hopeful acts of dense metaphorical meaning, signifying a habitus, a stance and life-style that lives out the novum of the new life in Christ, against waste and indignity; in a sense celebrating the advent of the pleroma, seeing the in-breaking telos of God's future with eyes of faith. The ways in which they re-purpose waste such as plastic, cardboard, garden and household refuse are truly creative, indeed playful, continuously seeing new possibilities in objects that other people no longer have any use for. In the process, they have become a powerful metaphor for a liturgy of repurposing, reminding us that we urgently need such a liturgical theology of re-purposing, a liturgical habitus that takes us to the street - and on to the dump heap.

39 Cf. Fahmi, Wael \& Sutton, Keith 2006. Cairo's Zabbaleen Garbage Recyclers: Multinationals' Takeover and State Relocation Plans. Habitat International, Vol 30:820; Fahmi, Wael Salah 2005. The Impact of Privatization of Solid Waste Management on the Zabbaleen Garbage Collectors of Cairo. Environment \& Urbanization, Vol 17, no.2:158. A film has even been made of the Zabbaleen: Marina of the Zabbaleen, Directed by Engi Wassef. Produced by 'Torch Films.' 


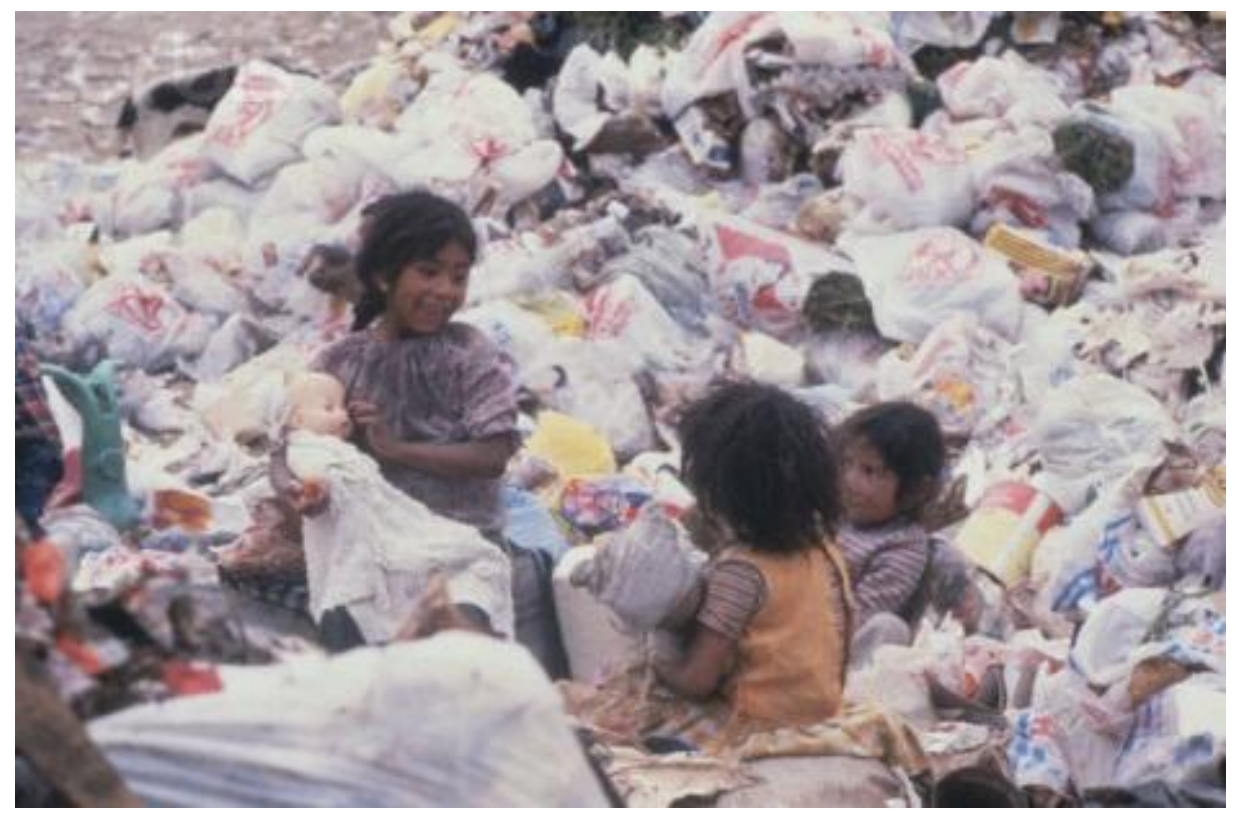

Like the children playing with their dolls amongst the waste of humanity - seen in the depiction above. The image of these children playing on the refuse dump symbolises the chaotic and polluted state of our planet, but perhaps it also represents - without the children knowing it - a playful, but purposeful protest against the waste on which they are sitting, and against those who allow this to be. Yes, perhaps their very childlike existence undermines the dump beneath them, giving glimpses of what could and should be - the grey children of God, playing in the fullness of pleroma, in God's new creation.

It may seem like a royal waste of time.

In fact it says: it's time to stop the royal waste. 